\author{
About authors: \\ Korobkeyev Alexander, MD, PhD, Professor; Head of Department of Anatomy; \\ tel.: +7(8652)353229; e-mail: Korobkeev@Stgma.ru \\ Dolgashova Marina, MD, PhD; Associate Professor, Department of Histology; \\ tel.: +7(8652)353440; e-mail: dolgashova@mail.ru \\ Lezhnina Oksana, MD, PhD; Associate Professor, Department of Anatomy; \\ tel.: +7(8652)353229; e-mail: okliz26@mail.ru
}

(๑) Group of autors, 2016

UDC 616.37-002-08

DOI - http://dx.doi.org/10.14300/mnnc.2016.11042

ISSN 2073-8137

\title{
RESULTS OF ACUTE PANCREATITIS TREATMENT IN SURGERY DEPARTMENT CLINIC OF STAVROPOL STATE MEDICAL UNIVERSITY
}

\author{
Suzdaltsev I. V., Ionov P. Sh., Pechenkin E. V., Bondarenko A. G., Panchenko A. S. \\ Stavropol State Medical University, Russian Federation

\section{РЕЗУАЬТАТЫ АЕЧЕНИЯ ОСТРОГО ПАНКРЕАТИТА В КАИНИКЕ ФАКУАЬТЕТСКОЙ ХИРУРГИИ СТАВРОПОАЬСКОГО ГОСУААРСТВЕННОГО МЕАИЦИНСКОГО УНИВЕРСИТЕТА}

\author{
И. В. СузАальцев, П. Ш. Ионов, Е. В. Печёнкин, А. Г. Бондаренко, А. С. Панченко \\ Ставропольский госуАарственный меАицинский университет, Российская ФеАерация
}

The analysis of results of treatment of patients with acute pancreatitis in the clinic of faculty surgery, Stavropol state medical University for 30 years. For the period 1984-2014 in the clinic of faculty surgery enrolled 4010 patients with acute pancreatitis. The leading etiological factor in the development of acute pancreatitis was alimentary. Overall mortality was $2.1 \%$. Of 4010 operated 321 (8\%), after surgery died 60 (18,6 \%) patients. Postoperative mortality in 1984-1997, he was $16.1 \%$, from 1998 to 2006 the values of this index varied in the range of $31 \%$, from 2007 to 2014 these numbers was of $13.8 \%$. This dynamics of postoperative mortality associated with the introduction of minimally invasive technologies. In patients treated conservatively, the mortality rate $0.7 \%$, which is due to the effectiveness of complex intensive pathogenetic therapy.

Key words: acute pancreatitis, analysis of the results, treatment

Проведён анализ результатов лечения больных острым панкреатитом в клинике факультетской хирургии Ставропольского государственного медицинского университета за 30 лет. За период 1984-2014 гг. в клинику факультетской хирургии поступило 4010 больных с острым панкреатитом. Ведущим этиологическим фактором в развитии острого панкреатита являлся алиментарный. Общая летальность составила $2,1 \%$. Из 4010 прооперировано 321 (8 \%), после операции умерло 60 (18,6 \%) больных. Послеоперационная летальность в 1984-1997 гг. составляла 16,1%, с 1998 по 2006 г. значения этого показателя варьировали в пределах 31 \%, начиная с 2007 по 2014 г. эти цифры соответствали 13,8 \%. Данная динамика послеоперационной летальности связана с внедрением малоинвазивных технологий. У больных, пролеченных консервативно, летальность составила 0,7 \%, что объясняется эффективностью комплексной интенсивной патогенетической терапией.

Ключевые слова: острый панкреатит, анализ результатов, лечение

P atients with acute pancreatitis account for $5-10 \%$ of the entire number of patients that belong to the surgical profile [3]. The latest decade has witnessed a rapidly increasing number of cases of acute pancreatitis, which has changed significantly the total structure of pathologies requiring emergency surgery. Acute pancreatitis tops the list of all other urgent abdominal issues - in 2004 the share of cases with acute pancreatitis was $31.3 \%$ out of the entire number of surgical hospitalizations, while in 1997 the patients in question made up only $21.5 \%$ of the entire number in the respective pathology group. In 2015, many regions had acute pancreatitis as the top common issue leaving behind all other urgent surgical abdominal pathologies [1]. 15-20\% of observed acute pancreatitis cases prove of destructive nature. In 40-70\% of patients with pancreatonecrosis get infected foci of necrotic destruction $[4,5]$. The mortality rate due to acute pancreatitis is up to $30 \%$. Infectious complications preceded by destructive pancreatitis account for $80 \%$ of the respective deaths [2]. Even though the methods for treating the disease have been improving for the latest $\mathbf{3 0}$ years, the mortality rate still remains 
at $4-40 \%$, while in certain, most complicated cases it may go up to $90 \%[3,5]$.

Aim of study was to analyze the treatment outcomes for acute pancreatitis within 1984-2014 yars.

Material and Methods. Within the above-mentioned period at the Department Surgery of StSMU has had 4,010 patients hospitalized with acute pancreatitis, 1,604 $(40 \%)$ of them being males while the number of females was $2,406(60 \%)$, which offers a ratio of $1: 1.5$. Aged up to 30 were 397 ( $9.9 \%$ ) patients; $31-59$ years old were 2,149 (53.6 \%), and another 1,464 (36.5\%) patients could be referred to as elderly and old. The structure of the disease had acute pancreatitis of alimentary etiology topping the list, including alcohol-induced pancreatitis $(1,604$ patients, i.e. $40 \%$ ), which was immediately followed by gallstone pancreatitis with 1,363 (34\%) cases, while $461(11.5 \%)$ patients had certain traumas, and another $461(115 \%)$ - other or unidentified causes behind the issue (acute pancreatitis was classified as idiopathic). 321 ( $8 \%$ ) patients out of the 4,010 underwent surgeries, with $60(18.6 \%)$ patients passing away after the surgery. Of 3,689 cases that were given conservative treatment, $26(0.7 \%)$ passed away, which brought the total rate of mortality to $2.1 \%$.

Results. In view of the significant changes in treatment practices for acute pancreatitis, it appeared a reasonable idea to analyze the respective treatment outcomes for the latest 30 years. The chosen period of time was broken in three parts while the patients were divided in three groups. Group 1 included 1,036 patients with various clinical-morphological types of acute pancreatitis who underwent treatment in the clinic within 1984-1997 (80 patients annually on the average). Group 2 was made up of 781 patients, each hospitalized at a certain point within the range of 1998-2006, whereas the annual influx of patients suffering from acute pancreatitis was at about 98 cases. Period 3 (2007-2014) involved 1,648 patients hospitalized (182 patients per year on the average).

The surgical treatment given to the patients of Group 1 featured a relatively high rate of laparotomy at the stage of enzyme toxemia (12\% of the patients operated on, while in Group 2 this frequency rate was $3.7 \%$ only). The surgical tactics in Group 2 implied no early laparotomy surgeries, yet delayed invasions in case of inefficiency detected after a set of intensive care measures, and in cases of infected pancreatonecrosis. Those were single

\section{References}

1. Brekhov E. I., Reshetnikov E. A., Mironov A. S. Diagnosis and treatment of sterile necrotizing pancreatitis. Khirurgiya. - Surgery. 2006;9:31-35.

2. Nesvaderani M., Eslick G. D., Vagg D. Epidemiology, etiology and outcomes of acute pancreatitis: A retrospective cohort study. International Journal of Surgery. 2015;23:68-74.

3. Stevenson K., Carter C. R. Acute pancreatitis. Surgery.2013;31(6):295-303. surgeries, as well as in the relaparotomy mode - planned and on request, while in the second and the third periods analyzed the range of indications for relaparotomy as planned was made wider. The post-surgery mortality rate went up from $16.1 \%$ in Group 1 to $31 \%$ in Group 2 , which is largely related to a lower number of surgeries in the latter group. From 2007 on (Period 3), the clinic was actively employing minimally invasive technologies: percutaneous puncture invasion under ultrasonic control, and laparoscopies. All the operations under ultrasonic monitoring were performed with locally applied anesthetics. Ultrasonic control was used for 80 drains of infected cysts and abscesses at the pancreas area; 10 drains for sub-diaphragmatic abscesses, and 10 abscesses in the retroperitoneal tissue; and 10 percutaneous cholecystostomies were performed. Of the $110(6.7 \%)$ patients that underwent surgeries via minimally invasive technologies, 10 passed away, thus accounting for a mortality rate of $11 \% .78(4.7 \%)$ patients were operated on in conventional ways with a mortality rate of $20.8 \%$ (16 patients). Therefore, a total of $188(6.4 \%)$ patients underwent surgeries in Period 3 with a mortality rate of $13.8 \%$ (26 patients).

Of the 912 (88 \%) patients who were given conservative therapy within Period, $26(2.8 \%)$ passed away. In Group 2, of the 752 (96.3\%) patients who got conservative treatment no deaths were registered. Of the $1,460(88.6 \%)$ patients in Group 3, who were treated conservatively, too, no deaths were reported either.

Conclusions. The average number of cases hospitalized with acute pancreatitis within 2007-2014 went up 2.3 times compared to the period of 1984-1997. Over a half of all the patients $(63.5 \%)$ were in their working age. Alimentary factor proved the leading one in the etiology of acute pancreatitis. This suggests that the issue of acute pancreatitis implies both medical \& social aspects. Due to the fact that edematous types are prevalent in the structure of the issue, the total mortality rate within the period analyzed remained at around $2.1 \%$. A decrease in the post-surgery mortality observed in the recent years is due, first of all, to the introduction of technologies requiring minimum invasion. The mortality rate among the patients that underwent conservative treatment was $0.7 \%$, which could be accounted for the efficiency of comprehensive intensive pathogenetic therapy.

4. Suzdaltsev I. V., Bondarenko A. G., Demyanova V. N. Analysis of complications in puncture-draining minimally invasive surgery. Medicinskii vestnik Severnogo Kavkaza. - Medical news of North Caucasus. 2014;9(3):224-226.

5. Zurnadzhanc V. A., Kichibekov E. A., Serdyukov M. A. Acute pancreatitis, diagnosis and prognosis. Medicinskii Vestnik Yuga Rossii. - Medical bulletin of the South Russia. 2014;4:42-44.

\section{About authors:}

Suzdaltsev Igor, MD, PhD, Professor, Head of Department for Departmental Surgery with a Course in Urology; tel.: +7(8652)561700; e-mail: suzdalsev@yandex.ru

Ionov Petr, MD, Associate Professor, Department for Departmental Surgery with a Course in Urology; tel.: +79064706581; e-mail: ionov@mail.ru

Pechenkin Evgeny, MD, Associate Professor, Department for Departmental Surgery with a Course in Urology; tel.: +79624019450; e-mail: pevgeny@inbox.ru

Bondarenko Alexander, MD, Associate Professor, Department for Departmental Surgery with a Course in Urology; tel.: +79097590083; e-mail: montess@yandex.ru

Panchenko Alexander, Post-Graduate Student of Department for Departmental Surgery with a Course in Urology; tel.: +79887371117; e-mail: Cremberis@mail.ru 